\title{
Cytotoxic and Apoptosis-Inducing Activities of 12-O-Acetylazedarachin B from the Fruits of Melia azedarach in Human Cancer Cell Lines
}

\author{
Takashi Kikuchi, ${ }^{a, b}$ Xin Pan, ${ }^{a}$ Koichi Ishii, ${ }^{a}$ Yasuhiro Nakamura, ${ }^{a}$ Eri Ogihara, ${ }^{a}$ Kazuo Koike, ${ }^{c}$ \\ Reiko Tanaka, ${ }^{b}$ and Toshihiro Akihisa* ${ }^{* a}$ \\ ${ }^{a}$ College of Science and Technology, Nihon University; 1-8-14 Kanda Surugadai, Chiyoda-ku, Tokyo 101-8308, \\ Japan: ${ }^{b}$ Osaka University of Pharmaceutical Sciences; 4-20-1 Nasahara, Takatsuki, Osaka 569-1094, Japan: and \\ ${ }^{c}$ School of Pharmaceutical Sciences, Toho University; 2-2-1 Miyama, Funabashi, Chiba 274-8510, Japan. \\ Received September 10, 2012; accepted October 16, 2012
}

12-O-Acetylazedarachin B (1), isolated from the fruit extract of Melia azedarach, exhibited potent cytotoxicity against leukemia $(\mathrm{HL}-60)\left(\mathrm{IC}_{50} 0.016 \mu \mathrm{M}\right)$ and stomach $(\mathrm{AZ521})\left(\mathrm{IC}_{50} \mathbf{0 . 0 3 5} \mu \mathrm{M}\right)$ cancer cell lines. Upon assessing the apoptosis-inducing activity in HL-60 cells, compound 1 exhibited induction of apoptosis detected by the observation of membrane phospholipid exposure and DNA fragmentation in flow cytometry. Western blot analysis showed that 1 markedly reduced the levels of procaspases-3, 8, and 9, while being increased the levels of cleaved caspases-3, 8, and 9. In addition, compound 1 increased significantly Bax/Bcl-2 ratio. These results suggested that 1 induced apoptotic cell death in HL-60 via both mitochondrial and death receptor-mediated pathways. Therefore, compound 1 may be promising lead compound for developing an effective drug for treatment of leukemia. Flow cytometric analysis suggested that the cytotoxicity of 1 against AZ521 is due to inducing apoptosis as well as necrosis with the latter predominated.

Key words 12-O-acetylazedarachin B; Melia azedarach; cytotoxic activity; apoptosis; limonoid

Plants of the Meliaceae family have been well documented for the ability to metabolize structurally diverse and biologically significant limonoids and triterpenoids. ${ }^{1)}$ Melia azedarach L. (Meliaceae) is indigenous to Japan, Taiwan, China, and Southeast Asia. Its bark and fruit, which are known as "Kurenpi" and "Kurenshi," respectively, in Japan, have been used for vermicide, anodyne, and skin disease., ${ }^{2,3)}$ Many constituents including limonoids, triterpenoids, and steroids have been isolated from various parts of $M$. azedarach. ${ }^{4-8)}$ Several of the limonoids isolated from $M$. azedarach have been reported to possess cytotoxic, ${ }^{9)}$ antifeeding, ${ }^{10)}$ and insecticidal activities. ${ }^{11)}$ In the course of a search for potential bioactive compounds from Meliaceae plants, we have undertaken a detailed investigation on the limonoid constituents of $\mathrm{Aza}$ dirachta indica (néem) seed extracts and have shown that some limonoids exhibit potent inhibitory activities against melanogenesis in B16 melanoma cells, against 12-O-tetradecanoylphorbol-13-acetate (TPA)-induced inflammation in mice, and against TPA-induced Epstein-Barr virus early antigen (EBV-EA) activation, ${ }^{12,13)}$ as well as cytotoxic and apoptosisinducing activities. ${ }^{14)}$ In a continuing study on the limonoid constituents of Meliaceae plants, we have investigated the fruit extract of $M$. azedarach, and have isolated a trichilintype limonoid, 12-O-acetylazedarachin B (1), which exhibited about 100-times higher cytotoxic activities against leukemia (HL-60) and stomach (AZ521) cancer cell lines than those of a positive control, cisplatin. Therefore, it might be useful for the development of an effective cancer drug to reveal the underlying mechanism of cytotoxic action by $\mathbf{1}$. In this paper, we report the isolation and identification of $\mathbf{1}$, the induction of apoptosis in HL-60 and AZ521 cells by 1, and the mechanisms of the apoptotic cell death.

The authors declare no conflict of interest

\section{MATERIALS AND METHODS}

General NMR spectra were recorded with a JEOL ECX-400 $\left({ }^{1} \mathrm{H}, 400 \mathrm{MHz} ;{ }^{13} \mathrm{C}, 100 \mathrm{MHz}\right)$ spectrometer in $\mathrm{CDCl}_{3}$ with tetramethylsilane as an internal standard. Electrospray ionization (ESI)-MS was recorded on an Agilent $1100 \mathrm{LC} /$ MSD time-of-flight (TOF) system [ionization mode: positive; nebulizing gas $\left(\mathrm{N}_{2}\right)$ pressure: 35 psig; drying gas $\left(\mathrm{N}_{2}\right)$ : flow, $12 \mathrm{~L} / \mathrm{min}$; temp: $325^{\circ} \mathrm{C}$; capillary voltage: $3000 \mathrm{~V}$; fragmentor voltage: $225 \mathrm{~V}$ ]. Silica gel (silica gel 60, 230-400 mesh, Merck) and $\mathrm{C}_{18}$ silica (Chromatorex-ODS, 100-200 mesh; Fuji Silysia Chemical, Ltd., Aichi, Japan) were used for open column chromatography. Reversed-phase (RP) preparative HPLC (with refractive index detector) was carried out on a Pegasil ODS-II $5 \mu \mathrm{m}$ column $(25 \mathrm{~cm} \times 10 \mathrm{~mm}$ i.d.; Senshu Scientific Co., Ltd., Tokyo, Japan) at $25^{\circ} \mathrm{C}$ with $\mathrm{MeCN}-\mathrm{H}_{2} \mathrm{O}-\mathrm{AcOH}$ (50:50:0.1; flow rate, $3.0 \mathrm{~mL} / \mathrm{min}$ ) as the solvent system.

Material Mature fruits of Melia azedarach L. (Meliaceae) were collected from plants cultivated at the Toho University herbal garden (Funabashi, Chiba, Japan) on 31st January, 2008. The plant material was authenticated by one (K. K.) of the authors, and a voucher specimen was deposited in the herbarium of the School of Pharmaceutical Sciences, Toho University. Chemicals and reagents were purchased as follows: fetal bovine serum (FBS) from Roswell Park Memorial Institute (RPMI); 1640 medium, antibiotics (100 units/mL penicillin and $100 \mu \mathrm{g} / \mathrm{mL}$ streptomycin), and non-essential amino acid (NEAA) from Invitrogen Co. (Grand Island, NY, U.S.A.); Dulbecco's modified Eagle's medium (DMEM), Eagle's minimal essential medium (MEM), and thiazoyl blue tetrazolium bromide (MTT) from Sigma-Aldrich Japan Co. (Tokyo, Japan); and rh annexin V/FITC kit (Bender MedSystems) from Cosmo Bio Co., Ltd. (Tokyo, Japan). All other chemicals and reagents were of analytical grade.

Cell Cultures Cell lines HL-60 (leukemia), AZ521 (stomach), A549 (lung), and SK-BR-3 (breast) were obtained from Riken Cell Bank (Tsukuba, Ibaraki, Japan). Two cell lines, 
HL-60 and SK-BR-3, were grown in RPMI 1640 medium, while A549 and AZ521 cell lines were grown in DMEM and in $90 \% \mathrm{DMEM}+10 \% \mathrm{MEM}+0.1 \mathrm{~mm}$ NEAA, respectively. The medium was supplemented with $10 \%$ FBS and antibiotics. Cells were incubated at $37^{\circ} \mathrm{C}$ in a $5 \% \mathrm{CO}_{2}$ humidified incubator.

Isolation Procedure The air-dried fruits of $M$. azedarach $(19.7 \mathrm{~kg})$ were pulverized and extracted with $n$-hexane $(2 \mathrm{~L} \times 3$, $2 \mathrm{~h}$ each) under reflux, which gave an $n$-hexane extract $(695 \mathrm{~g})$. The defatted residue was, then, extracted with methanol $(\mathrm{MeOH})(2 \mathrm{~L} \times 3,3 \mathrm{~d}$ each $)$ at room temperature to give $\mathrm{MeOH}$ extract $(1036 \mathrm{~g})$. The $\mathrm{MeOH}$ extract was suspended in water and partitioned with EtOAc to afford EtOAc (103 g) and $\mathrm{H}_{2} \mathrm{O}$ fractions. A portion of EtOAc fraction $(91 \mathrm{~g})$ was subjected to chromatography on a $\mathrm{SiO}_{2}$ column $(800 \mathrm{~g})$. Step gradient elution was conducted with $n$-hexane-EtOAc $(1: 0 \rightarrow 0: 1)$ to give 11 fractions: A-K, listed in increasing order of polarity. Fraction $\mathrm{H}(3.81 \mathrm{~g})$, eluted with $n$-hexane-EtOAc $(2: 3)$, was subjected to further chromatography on silica gel $[100 \mathrm{~g}$; eluent: $n$-hexane-EtOAc $(4: 1 \rightarrow 0: 1)]$ to afford 11 fractions, H1-H11. Preparative HPLC of fraction H8 $(292 \mathrm{mg})$, eluted with $n$ hexane-EtOAc (11:9), gave compound 1 (4.2 $\left.\mathrm{mg}, t_{\mathrm{R}} 24.0 \mathrm{~min}\right)$.

Cytotoxicity Assay Cytotoxicity assay was performed according to the method previously reported ${ }^{15,16)}$ with HL-60, AZ521, A549, and SK-BR-3 cell lines (each $3 \times 10^{3}$ cells in $100 \mu \mathrm{L})$.

Annexin V-Propidium Iodide (PI) Double Staining Annexin V-propidium iodide (PI) double staining was performed according to the method previously reported ${ }^{15,16)}$ with HL-60 (10 cells in $5000 \mu \mathrm{L})$ and AZ521 $\left(10^{5}\right.$ cells in $\left.5000 \mu \mathrm{L}\right)$.

Cell Cycle Analysis Cell cycle analysis was performed according to the method previously reported ${ }^{16)}$ with HL-60 $\left(10^{5}\right.$ cells in $\left.5000 \mu \mathrm{L}\right)$.

Western Blot Analysis Western blot analysis was performed according to the previous method ${ }^{15,16)}$ with HL-60 cells $\left(1 \times 10^{5}\right.$ cells in $\left.5000 \mu \mathrm{L}\right)$.

\section{RESULTS AND DISCUSSION}

12-O-Acetylazedarachin B (1) (Fig. 1) was isolated from the $\mathrm{MeOH}$ extract of defatted Melia azedarach fruit by silica gel column chromatography and RP preparative HPLC. Identification of 1 was performed by ${ }^{1} \mathrm{H}$ - and ${ }^{13} \mathrm{C}-\mathrm{NMR}$, and ESI-MS spectroscopic comparison with literature data. ${ }^{17)}$ The cytotoxic activity of compound $\mathbf{1}$ and two anticancer drugs, cisplatin and 5-fluorouracil (5-FU), were evaluated against four human cancer cell lines, HL-60 (leukemia), AZ521 (stomach), A549 (lung), and SK-BR-3 (breast), by means of a MTT assay, and the results are summarized in Table 1. Compound $\mathbf{1}$ exhibited superior cytotoxic activity to positive controls against three

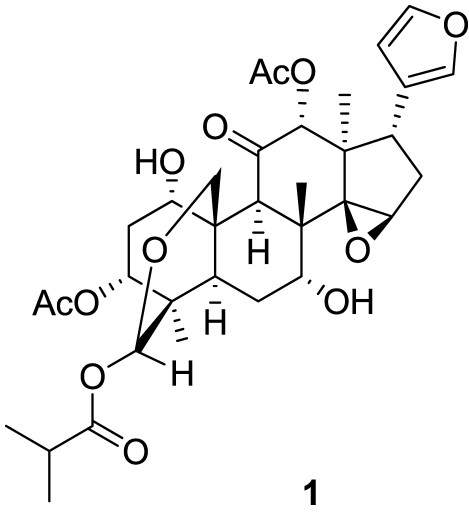

Fig. 1. Structure of Compound $\mathbf{1}$

cell lines, HL-60, AZ521, and A549. In particular, the cytotoxicities of compound 1 against HL-60 $\left(\mathrm{IC}_{50} 0.016 \mu \mathrm{M}\right)$ and AZ521 $\left(\mathrm{IC}_{50} 0.035 \mu \mathrm{M}\right)$ cells were about 100-times higher than those of cisplatin [ $\mathrm{IC}_{50} 4.2 \mu \mathrm{M}$ (HL-60) and 9.5 $\mu \mathrm{M}$ (AZ521)]. Compound 1, however, did not show cytotoxicity against SK-BR-3 cells. The potent cytotoxicity of 1 against HL-60 and AZ521, and non-activity against SK-BR-3 might be due to the presence of a cell-specific receptor that differentiates one tumor-type from another. ${ }^{18)}$ It is suggested that the target receptor of compound 1 does not exist in A549 and SK-BR-3 cells, or, if it existed, the receptor activated the anti-apoptotic signaling pathway. The cytotoxic and apoptosis inducing activities of compound 1 against HL-60 cells have been patented recently. ${ }^{19)}$ Melia azedarach have been known to contain various trichilin-type limonoids, and it was reported that trichilintype limonoids possessing one or two acetoxy groups in the structures exhibited strong cytotoxic activities against P388 mouse leukemia cells. ${ }^{20,21)}$ Since compound $\mathbf{1}$ is a trichilintype limonoid with two acetoxy groups at C-3 and C-12 along with two hydroxy groups at $\mathrm{C}-1$ and $\mathrm{C}-7$, and showed potent cytotoxicities against HL-60 and AZ521 cells, this supports the previous finding on the structure-cytotoxicity relationships. $^{20,21)}$

In order to explore the nature of cytotoxicity of compound 1, this was subjected to annexin V-fluorescein isothiocyanate (FITC) and propidium iodide (PI) double staining for detection of early apoptotic cells, and 4,6-diamidino-2-phenylindol (DAPI) staining for cell cycle analysis.

Compound 1 was evaluated for its apoptosis-inducing activity by flow cytometry of HL-60 cells stained with annexin V-FITC and PI. Exposure of the membrane phospholipid, phosphatidylserine, to the external cellular environment is one of the earliest markers of apoptotic cell death. ${ }^{22}$ Annexin V is a calcium-dependent phospholipid binding protein with high

Table 1. Cytotoxic Activities on Four Human Cancer Cell Lines of 12-O-Acetylazedarachin B (1) and Reference Compounds

\begin{tabular}{lcccc}
\hline \hline \multirow{2}{*}{ Compound } & \multicolumn{3}{c}{$\mathrm{IC}_{50}(\mu \mathrm{M})^{a)}$} \\
\cline { 2 - 5 } & HL-60 (leukemia) & AZ521 (stomach) & A549 (lung) & SK-BR-3 (breast) \\
\hline 12-O-Acetylazedarachin B (1) & 0.016 & 0.035 & 19.0 & $>100$ \\
Cisplatin $^{b)}$ & 4.2 & 9.5 & 24.9 & 18.8 \\
5-Fluorouracil (5-FU) & 9.1 & 28.7 & $>100$ & $>100$ \\
\hline
\end{tabular}

a) Cells were treated with compounds $\left(1 \times 10^{-4}-1 \times 10^{-9} \mathrm{M}\right)$ for $48 \mathrm{~h}$, and cell viability was analyzed by the MTT assay. The IC $\mathrm{In}_{50}$ value is the concentration of compound required to inhibit the growth of the cells by $50 \%$. This was obtained based on triplicate assay results. $b$ ) Reference compound. 

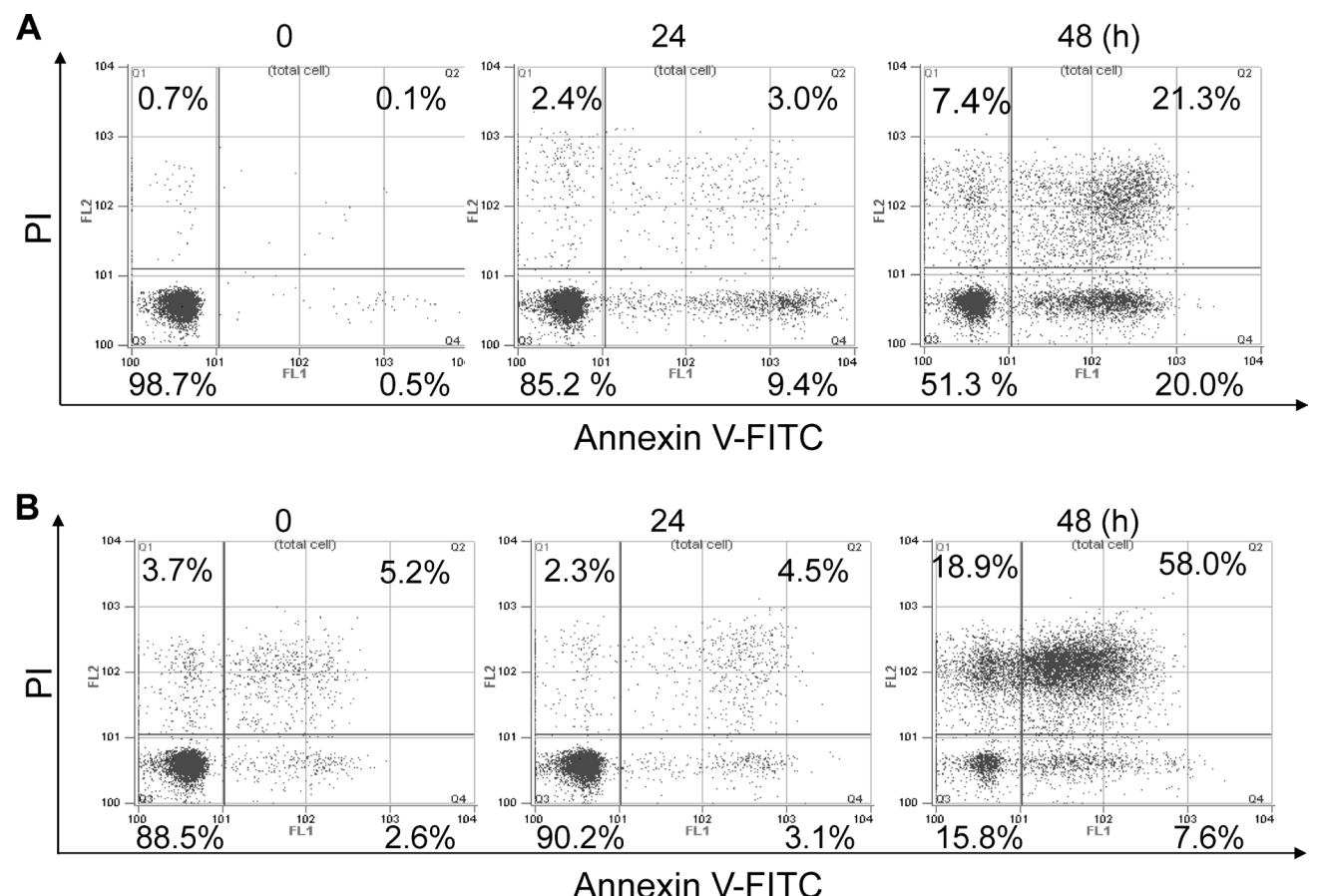

Fig. 2. Compound 1 Induced Apoptosis against HL-60 and AZ521 Cells

(A) HL-60 cells were cultured with 1 ( $50 \mathrm{~nm}$ ) for 24 and $48 \mathrm{~h}$. (B) AZ521 cells were cultured with 1 (50 nM) for 24 and $48 \mathrm{~h}$. The results are from one representative experiment among three runs, which showed similar patterns to one another.

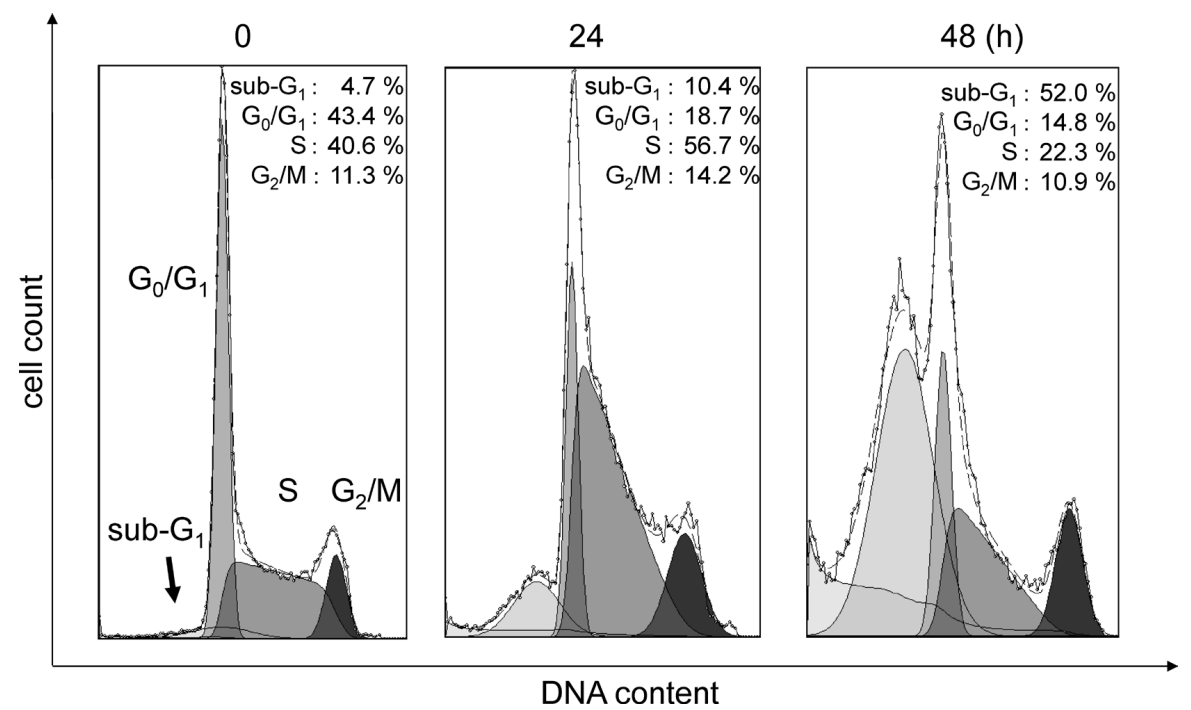

Fig. 3. Cell Cycle Analysis of HL-60 Cells Treated with Compound 1 (50 nm) for 0, 24, and 48h

The results are from one representative experiment among three runs, which showed similar patterns to one another.

affinity for phosphatidylserine expressed on the cell surface. PI does not enter a cell with intact cell-membrane and was used to differentiate between early apoptotic (annexin V-positive, PI-negative), late apoptotic (annexin V-, PI-double positive), or necrotic cell death (annexin V-negative, PI-positive). The ratio of early apoptotic cells (lower right) was increased after treatment with compound 1 (50 nM) in HL-60 for $24 \mathrm{~h}$ (from 0.5 to $9.4 \%$ ) and $48 \mathrm{~h}(20.0 \%)$, and that of late apoptotic cells (upper right) was increased after $24 \mathrm{~h}$ (from 0.1 to $3.0 \%$ ) and $48 \mathrm{~h}(21.3 \%)$ (Fig. 2A). These results revealed that most of the cytotoxic activity of compound $\mathbf{1}$ against HL-60 cells is due to inducing apoptotic cell death.
Compound 1 was further evaluated for apoptosis-inducing activity against AZ521 cells by means of annexin V and PI double staining. The ratio of early apoptotic cells was increased, but only in a slight extent, after treatment with compound $1(50 \mathrm{~nm})$ for $24 \mathrm{~h}$ (from 2.6 to $3.1 \%$ ) and for $48 \mathrm{~h}(7.6 \%)$, and that of late apoptotic cells was increased significantly for $48 \mathrm{~h}$ (from 5.2 to $58.0 \%$ ) (Fig. 2B). The ratio of necrotic cells (upper left) was, however, also increased after treatment with the compound for $48 \mathrm{~h}$ (from 3.7 to $18.9 \%$ ). These results suggested that cytotoxicity of compound $\mathbf{1}$ against AZ521 cells is due to inducing apoptotic cell death as well as necrotic cell death with the latter predominated. 
$\begin{array}{lllllll}\text { A } & 0 & 12 & 24 & 36 & 48 & (\mathrm{~h})\end{array}$

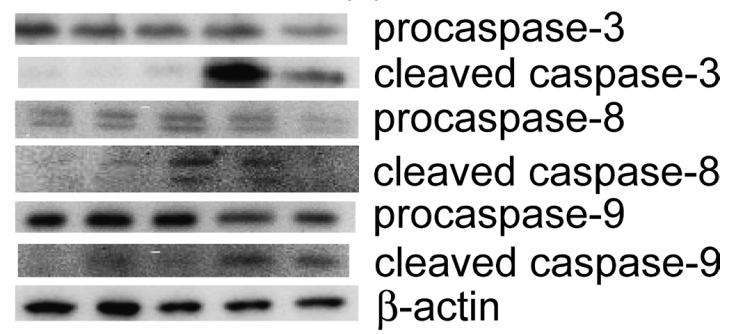

$\begin{array}{lllllll}\text { B } & 0 & 12 & 24 & 36 & 48 & (\mathrm{~h})\end{array}$

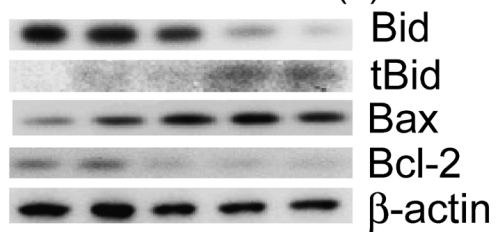

Fig. 4. Western Blot Analysis of HL-60 Cells Treated with Compound 1

(A) Western blot analysis of caspases-3, -8, and -9 in HL-60 cells with 1 (50 nM) for 12, 24, 36, and $48 \mathrm{~h}$. (B) Western blot analysis of Bid, tBid, Bax, and Bcl-2 in HL-60 cells with $1(50 \mathrm{~nm})$ for $12,24,36$, and $48 \mathrm{~h}$. The results are from one representative experiment among three runs, which showed similar patterns to one another.

Next, HL-60 cells were incubated with compound 1 (50 nm) for 24 and $48 \mathrm{~h}$, and then the cells were analyzed in terms of cell cycle distribution by means of flow cytometry. The sub- $\mathrm{G}_{1}$ peak, i.e., fragmented DNA, was quantified as the apoptosis index. ${ }^{23)}$ After treatment of $\mathbf{1}$, the sub- $\mathrm{G}_{1}$ peak increased in a time-dependent manner [from $4.7 \%$ to $10.2(24 \mathrm{~h})$ and $52.0 \%$ (48h) (Fig. 3)]. These results suggested that the cells had undergone apoptotic cell death after treatment with compound $\mathbf{1}$.

Caspases are known to mediate the apoptotic pathway. ${ }^{24,25)}$ In order to clarify the mechanism by which compound $\mathbf{1}$ induces apoptotic cell death in HL-60 cells, activation of caspases-3, -8 , and -9 was evaluated by Western blot analysis. Cleaved caspases-3, -8 , and -9 were expressed after treatment of HL-60 with compound 1 ( $50 \mathrm{~nm})$ for 12,24 , and $36 \mathrm{~h}$, respectively (Fig. 4A). These results indicated that compound 1 induced apoptotic cell death via both the mitochondrial and death receptor mediated pathways by activation of caspases-3, -8 , and -9 in HL-60 cells. Next, we assessed the effect of compound 1 on Bid, truncated-Bid (tBid), Bax, and Bcl-2. The pro-apoptotic proteins $\mathrm{Bax}$ and $\mathrm{Bid}$, and the anti-apoptotic mitochondrial protein Bcl-2 are important regulators of cytochrome $c$ release from mitochondria. ${ }^{26,27)}$ Expression of these proteins was investigated by Western blot analysis. Treatment of HL-60 cells by compound 1 ( $50 \mathrm{~nm})$ decreased the level of Bid and increased the level of tBid in a time-dependent manner (Fig. 4B). It was reported that caspase- 8 could truncate $\mathrm{Bid}$, and tBid could activate the mitochondrial pathway. ${ }^{28)}$ In addition, treatment of HL-60 cells by 1 decreased the level of Bcl-2 while increased the level of Bax (Fig. 4B). The Bax/ $\mathrm{Bcl}-2$ ratio is one of the indices of the intrinsic mechanism of apoptosis in mitochondria. ${ }^{29)}$ Since compound $\mathbf{1}$ increased this ratio in HL-60 cells, it seems that compound $\mathbf{1}$-induced apoptosis involved $\mathrm{Bax} / \mathrm{Bcl}-2$ signal transduction. Compound $\mathbf{1}$ is, therefore, suggested to induce apoptosis in HL-60 cells by involving both the mitochondrial- and death receptor-signal transduction pathways. It was reported that Fas receptor, a known death receptor which induces apoptosis, can activate the necrotic pathway. ${ }^{30)}$ The necrotic cell death of AZ521 by compound 1 was, therefore, supposed to be induced by the participation of Fas receptor signaling although it is not certain whether caspase- 8 is activated by Fas receptor.

Plant secondary metabolites and their semi-synthetic derivatives continue to play an important role in anticancer drug therapy. ${ }^{31)}$ From the results of cytotoxicity test, compound 1, which induced apoptotic cell death via both the mitochondrialand death receptor-mediated pathways in leukemia cells, may be a promising lead compound for developing an effective drug for leukemia.

Acknowledgment This work was supported, in part, by a Grant-in-Aid from the Japan Society for the Promotion of Science (No. 23590017), 2011-2013.

\section{REFERENCES}

1) Tan QG, Luo XD. Meliaceous limonoids: chemistry and biological activities. Chem. Rev., 111, 7437-7522 (2011).

2) Namba T. The Encyclopedia of Wakan-Yaku (Traditional Sino-Japanese Medicines) with Color Pictures. Revised ed., Hoikusya, Osaka, Vol. I, pp. 247-248 (1994).

3) Newly Revised Illustrated Medicinal Plants of World. (Okada M ed.) Hokuryukan Publishing Co., Ltd., Tokyo, p. 262 (2002).

4) Liu HB, Zhang CR, Dong SH, Dong L, Wu Y, Yue JM. Limonoids and triterpenoids from the seeds of Melia azedarach. Chem. Pharm. Bull., 59, 1003-1007 (2011).

5) Wu SB, Bao QY, Wang WX, Zhao Y, Xia G, Zhao Z, Zeng H, Hu JF. Cytotoxic triterpenoids and steroids from the bark of Melia azedarach. Planta Med., 77, 922-928 (2011).

6) Ntalli NG, Cottiglia F, Bueno CA, Alché LE, Leonti M, Vargiu S, Bifulco E, Menkissoglu-Spiroudi U, Caboni P. Cytotoxic tirucallane triterpenoids from Melia azedarach fruits. Molecules, 15, 5866-5877 (2010).

7) Zhou H, Hamazaki A, Fontana JD, Takahashi H, Wandscheer CB, Fukuyama Y. Cytotoxic limonoids from Brazilian Melia azedarach. Chem. Pharm. Bull., 53, 1362-1365 (2005).

8) Su ZS, Yang SP, Zhang S, Dong L, Yue JM. Meliarachins A-K: Eleven Limonoids from the twigs and leaves of Melia azedarach. Helv. Chim. Acta, 94, 1515-1526 (2011).

9) Zhou H, Hamazaki A, Fontana JD, Takahashi H, Esumi T, Wandscheer CB, Tsujimoto H, Fukuyama Y. New ring C-seco limonoids from Brazilian Melia azedarach and their cytotoxic activity. J. Nat. Prod., 67, 1544-1547 (2004).

10) Nakatani M, Huang RC, Okamura H, Iwagawa $T$, Tadera $K$, Naoki H. Three new antifeeding meliacarpinins from Chinese Melia azedarach LinN. Tetrahedron, 51, 11731-11736 (1995).

11) Carpinella MC, Defago MT, Valladares G, Palacios SM. Antifeedant and insecticide properties of a limonoid from Melia azedarach (Meliaceae) with potential use for pest management. J. Agric. Food Chem., 51, 369-374 (2003).

12) Akihisa T, Noto T, Takahashi A, Fujita Y, Banno N, Tokuda $H$, Koike K, Suzuki T, Yasukawa K, Kimura Y. Melanogenesis inhibitory, anti-inflammatory, and chemopreventive effects of limonoids from the seeds of Azadirachta indica A. Juss. (neem). J. Oleo Sci., 58, 581-594 (2009).

13) Akihisa $T$, Takahashi A, Kikuchi T, Takagi M, Watanabe K, Fukatsu M, Fujita Y, Banno N, Tokuda H, Yasukawa K. The melanogenesis-inhibitory, anti-inflammatory, and chemopreventive effects of limonoids in $n$-hexane extract of Azadirachta indica A. Juss. (neem) seeds. J. Oleo Sci., 60, 53-59 (2011).

14) Kikuchi $T$, Ishii K, Noto $T$, Takahashi A, Tabata K, Suzuki T, Akihisa T. Cytotoxic and apoptosis-inducing activities of limonoids 
from the seeds of Azadirachta indica (Neem). J. Nat. Prod., 74, 866-870 (2011).

15) Kikuchi T, Nihei M, Nagai H, Fukushi H, Tabata K, Suzuki T, Akihisa T. Albanol A from the root bark of Morus alba L. induces apoptotic cell death in HL60 human leukemia cell line. Chem. Pharm. Bull., 58, 568-571 (2010).

16) Kikuchi T, Uchiyama E, Ukiya M, Tabata K, Kimura Y, Suzuki T, Akihisa T. Cytotoxic and apoptosis-inducing activities of triterpene acids from Poria cocos. J. Nat. Prod., 74, 137-144 (2011).

17) Huang RC, Okamura H, Iwagawa $T$, Nakatani M. The structures of azedarachins, limonoid antifeedants from Chinese Melia azedarach Linn. Bull. Chem. Soc. Jpn., 67, 2468-2472 (1994).

18) Kim J, Park EJ. Cytotoxic anticancer candidates from natural resources. Curr. Med. Chem. Anticancer Agents, 2, $485-537$ (2002).

19) Akihisa T, Suzuki T, Kikuchi T, Nakamura Y, Ishii K. Antitumor agents containing 12-O-acetylazedarachin B. JP Patent 2011037795 A (2011).

20) Itokawa H, Qiao ZS, Hirobe C, Takeya K. Cytotoxic limonoids and tetranortriterpenoids from Melia azedarach. Chem. Pharm. Bull., 43, 1171-1175 (1995).

21) Takeya K, Quio ZS, Hirobe C, Itokawa H. Cytotoxic trichilin-type limonoids from Melia azedarach. Bioorg. Med. Chem., 4, 13551359 (1996).

22) Martin SJ, Reutelingsperger CP, McGahon AJ, Rader JA, van Schie RCAA, LaFace DM, Green DR. Early redistribution of plasma membrane phosphatidylserine is a general feature of apoptosis regardless of the initiating stimulus: inhibition by overexpression of Bcl-2 and Abl. J. Exp. Med., 182, 1545-1556 (1995).
23) Darzynkiewicz Z, Bruno S, Del Bino G, Gorczyca W, Hotz MA, Lassota P, Traganos F. Features of apoptotic cells measured by flow cytometry. Cytometry, 13, 795-808 (1992).

24) Salvesen GS, Dixit VM. Caspases: intracellular signaling by proteolysis. Cell, 91, 443-446 (1997).

25) Thornberry NA, Lazebnik Y. Caspases: enemies within. Science, 281, 1312-1316 (1998).

26) Kluck RM, Bossy-Wetzel E, Green DR, Newmeyer DD. The release of cytochrome $c$ from mitochondria: a primary site for Bcl-2 regulation of apoptosis. Science, 275, 1132-1136 (1997).

27) Kluck RM, Esposti MD, Perkins G, Renken C, Kuwana T, BossyWetzel E, Goldberg M, Allen T, Barber MJ, Green DR, Newmeyer DD. The pro-apoptotic proteins, Bid and Bax, cause a limited permeabilization of the mitochondrial outer membrane that is enhanced by cytosol. J. Cell Biol., 147, 809-822 (1999).

28) Luo X, Budihardjo I, Zou H, Slaughter C, Wang X. Bid, a Bcl2 interacting protein, mediates cytochrome $c$ release from mitochondria in response to activation of cell surface death receptors. Cell, 94, 481-490 (1998).

29) Oltvai ZN, Milliman CL, Korsmeyer SJ. Bcl-2 heterodimerizes in vivo with a conserved homolog, Bax, that accelerates programmed cell death. Cell, 74, 609-619 (1993).

30) Matsumura H, Shimizu Y, Ohsawa Y, Kawahara A, Uchiyama Y, Nagata S. Necrotic death pathway in Fas receptor signaling. J. Cell Biol., 151, 1247-1256 (2000).

31) Pan L, Chai H, Kinghorn AD. The continuing search for antitumor agents from higher plants. Phytochem. Lett., 3, 1-8 (2010). 